\title{
In vitro and in vivo anti-malarial activity of plants from the Brazilian Amazon
}

\author{
Renata B. S. Lima ${ }^{1,2,3}$, Luiz F. Rocha e Silva ${ }^{1,2,3}$, Marcia R. S. Melo ${ }^{4}$, Jaqueline S. Costa', Neila S. Picanço ${ }^{1,2}$, \\ Emerson S. Lima ${ }^{5}$, Marne C. Vasconcellos ${ }^{5}$, Ana Paula A. Boleti ${ }^{5}$, Jakeline M. P. Santos ${ }^{5}$, Rodrigo C. N. Amorim', \\ Francisco C. M. Chaves ${ }^{6}$, Julia P. Coutinho ${ }^{7}$, Wanderli P. Tadei ${ }^{8}$, Antoniana U. Krettli and Adrian M. Pohlit ${ }^{7 *}$ (1)
}

\begin{abstract}
Background: The anti-malarials quinine and artemisinin were isolated from traditionally used plants (Cinchona spp. and Artemisia annua, respectively). The synthetic quinoline anti-malarials (e.g. chloroquine) and semi-synthetic artemisinin derivatives (e.g. artesunate) were developed based on these natural products. Malaria is endemic to the Amazon region where Plasmodium falciparum and Plasmodium vivax drug-resistance is of concern. There is an urgent need for new anti-malarials. Traditionally used Amazonian plants may provide new treatments for drug-resistant P. vivax and P. falciparum. Herein, the in vitro and in vivo antiplasmodial activity and cytotoxicity of medicinal plant extracts were investigated.
\end{abstract}

Methods: Sixty-nine extracts from 11 plant species were prepared and screened for in vitro activity against P. falciparum K1 strain and for cytotoxicity against human fibroblasts and two melanoma cell lines. Median inhibitory concentrations $\left(\mathrm{IC}_{50}\right)$ were established against chloroquine-resistant P. falciparum W2 clone using monoclonal anti-HRPII (histidine-rich protein II) antibodies in an enzyme-linked immunosorbent assay. Extracts were evaluated for toxicity against murine macrophages $\left(\mathrm{IC}_{50}\right)$ and selectivity indices $(\mathrm{SI})$ were determined. Three extracts were also evaluated orally in Plasmodium berghei-infected mice.

Results: High in vitro antiplasmodial activity $\left(\mathrm{IC}_{50}=6.4-9.9 \mu \mathrm{g} / \mathrm{mL}\right)$ was observed for Andropogon leucostachyus aerial part methanol extracts, Croton cajucara red variety leaf chloroform extracts, Miconia nervosa leaf methanol extracts, and Xylopia amazonica leaf chloroform and branch ethanol extracts. Paullinia cupana branch chloroform extracts and Croton cajucara red variety leaf ethanol extracts were toxic to fibroblasts and or melanoma cells. Xylopia amazonica branch ethanol extracts and Zanthoxylum djalma-batistae branch chloroform extracts were toxic to macrophages $\left(\mathrm{IC}_{50}=6.9\right.$ and $24.7 \mathrm{\mu g} / \mathrm{mL}$, respectively). Andropogon leucostachyus extracts were the most selective $(\mathrm{SI}>28.2)$ and the most active in vivo (at doses of $250 \mathrm{mg} / \mathrm{kg}, 71 \%$ suppression of $P$. berghei parasitaemia versus untreated controls).

Conclusions: Ethnobotanical or ethnopharmacological reports describe the anti-malarial use of these plants or the antiplasmodial activity of congeneric species. No antiplasmodial activity has been demonstrated previously for the extracts of these plants. Seven plants exhibit in vivo and or in vitro anti-malarial potential. Future work should aim to discover the anti-malarial substances present.

Keywords: Plasmodium falciparum, Plasmodium berghei, Antiplasmodial, Cytotoxic, Anacardium occidentale, Andropogon leucostachyus, Croton cajucara, Paullinia cupana, Xylopia amazonica, Zanthoxylum djalma-batistae

\footnotetext{
*Correspondence: ampohlit@gmail.com; ampohlit@inpa.gov.br

${ }^{1}$ Laboratório de Princípios Ativos da Amazônia, Coordenação de

Tecnologia e Inovação, Instituto Nacional de Pesquisas da Amazônia,

Avenida André Araújo, 2936, Petrópolis, 69067-375 Manaus, Amazonas,

Brazil

Full list of author information is available at the end of the article
} 


\section{Background}

In the Amazon region, the occurrence of malaria is related to demographic, ecological, socio-economic, and cultural changes, especially in the first half of the twentieth century. In this period, relatively few plants from this region were used to treat this disease $[1,2]$. Over time, the co-existence of traditional populations with this disease caused a search for new therapeutic resources in the Amazonian environment, especially among plants, to treat the symptoms of malaria. Nowadays, this traditional knowledge, available through ethnopharmacological studies, is the most often used means to target plants for the discovery of new bioactive substances. The ethnopharmacological approach has led to the saving of time and financial resources as compared to other approaches, such as chemosystematic or random plant selection $[3,4]$. The chemosystematic approach for the selection of anti-malarial plants for study is also valid especially where ethnopharmacological studies have shown a plant family, or a particular genus, to contain anti-malarial extracts and chemical constituents.

Natural products are the origin of approximately twothirds of all drugs introduced in the past 30 years [5]. Plants are recognized as important sources of antiprotozoal compounds for the development of drugs against many tropical diseases, including malaria. Examples of anti-malarial natural products are (1) quinine, present in western Amazonian Cinchona spp., (2) quassinoids and limonoids in plants of the Simaroubaceae and Meliaceae families, respectively, and, (3) artemisinin from Artemisia annua, among others [6, 7].

The Amazon region is megadiverse. Screening for in vitro and in vivo anti-malarial activity of extracts of traditionally used plants from this region is a strategy for the discovery of new anti-malarial substances [8-10]. Studies on the anti-malarial activity of plant species from countries of the Amazon region such as Bolivia [11-15], Brazil [16-29], Colombia [30], French Guiana [31-34], and Peru [35-38] have demonstrated the potential of local traditional medicinal practices as sources of potent extracts and anti-malarial substances.

Krettli and collaborators performed ethnobotanic surveys of anti-malarial plants across the Brazilian Amazon region and applied the ethnopharmacological approach to the study of these plants for the first time [1, 39]. Ethnopharmacology provided a relatively large number (4 in 22 plants or $18 \%$ ) of plants exhibiting extracts with in vivo efficacy against Plasmodium berghei compared to an approach based on random selection of plants (two active plants in 273 tested or $0.7 \%$ ) [40, 41].

In the present work, after a systematic literature search, 11 Amazonian plants were selected based on their use as anti-malarials or based on the proven anti-malarial activity of the plant genus. No previous report on the activity against Plasmodium parasites was found for the selected plant species. Their extracts were assayed for in vitro and in vivo anti-malarial activity and cytotoxicity. The aim of this study was to discover Amazonian plant extracts exhibiting important in vitro and in vivo antimalarial activity as a first step towards bioguided isolation of active principles. The plant species studied are shown in Table 1.

\section{Methods}

Collection, identification and processing of plant materials Initially, library and online (Web of Knowledge, Scopus, Scifinder Scholar, among others) surveys of the literature on plants traditionally used as anti-malarials were performed using the convenient search term 'antimalarials from plants'. Also, a survey of plant species exhibiting proven anti-malarial properties according to previous laboratory studies was performed. Registry (No. 33110-1) for the collection of plant materials was performed online through the Brazilian Government's Authorization and Information in Biodiversity System (SISBIO), Chico Mendes Biodiversity Conservation Institute (ICMBio), Ministry of Environment (MMA). Collection of the different parts of 11 Amazonian species was performed based on ethnobotanic information, where available. These were generally the more readily collected parts of each plant species (Table 1). Authorization for collection of plant materials at the National Institute for Amazon Research (INPA) Adolpho Ducke Forest Reserve, located in the municipality of Manaus, was obtained prior to collection. Plant materials from Embrapa Amazônia Ocidental's live plant collections were provided by Dr. Francisco Célio Maia Chaves. No in vitro and/or in vivo anti-malarial activity data were available for these plant species in the literature. Collection was performed from August to October 2012 in Amazonas State, Brazil. Vouchers were deposited and identified at the INPA and Federal Agrotechnical School of Manaus (EAFM) herbariums. Prior to extraction, plant materials were dried in the shade at ambient temperature (average of ca. $27^{\circ} \mathrm{C}$ ) for $72 \mathrm{~h}$ and then further dried in a circulating air oven at $40{ }^{\circ} \mathrm{C}$ for 7 days. The dry plant materials were ground and stored at $-20{ }^{\circ} \mathrm{C}$ until extraction was performed.

\section{Extraction of plant materials}

Ethanol (or methanol), water and chloroform extracts were prepared from each plant part (Table 1). Water extracts were prepared by infusing dry, ground plant materials in boiling de-ionized water $\left(100{ }^{\circ} \mathrm{C}, 3 \times 15 \mathrm{~min}\right)$ or when indicated in the literature, a decoction was prepared by boiling plant materials for $1 \mathrm{~h}$ under reflux. Ethanol, chloroform and methanol extractions were performed using 
Table 1 Information on plant species, voucher specimens, traditional remedies and ethnobotanic sources indicating anti-malarial use

\begin{tabular}{|c|c|c|c|c|c|}
\hline Species & Family & Accession number & Common name & Remedy & Source \\
\hline Anacardium occidentale & Anacardiaceae & INPA 57941 & Cajueiro & $\begin{array}{l}\text { Bark, leaves, fruit infusions, } \\
\text { decoction ( } 10 \text { drops } 2 \times 1 \\
\text { day of trunk bark alcohol } \\
\text { extract) }\end{array}$ & {$[58,68,82,96,109,113]$} \\
\hline Andropogon leucostachyus & Poaceae & INPA 250467 & Capim-colchão & Whole plant decoction & {$[58]$} \\
\hline Clidemia bullosa & Melastomataceae & INPA 250466 & Caiuia & Not found ${ }^{a}$ & Not found ${ }^{a}$ \\
\hline Croton cajucara & Euphorbiaceae & EAFM 315 & Sacaca & Bark and leaves infusions & {$[58,62-68]$} \\
\hline Derris floribunda & Fabaceae & INPA 15562 & Timbó & Branches & {$[58]$} \\
\hline Miconia nervosa & Melastomataceae & INPA 250467 & Miraúba & Decoction (part not specified) & {$[58]$} \\
\hline Parkia nítida & Fabaceae & INPA 152124 & Faveira & Not specified & {$[58]$} \\
\hline Paullinia cupana & Sapindaceae & INPA 122001 & Guaraná & Leaves, branches, roots, seeds & {$[58,63,96,97]$} \\
\hline Stigmaphyllon sinuatum & Malpighiaceae & INPA 205629 & Cipó asa de gafanhoto & Leaves decoction & {$[58]$} \\
\hline Xylopia amazonica & Annonaceae & INPA 183108 & Envira sarassará & Not found ${ }^{b}$ & Not found ${ }^{b}$ \\
\hline Zanthoxylum djalma-batistae & Rutaceae & INPA 210077 & Tamanqueira & Not found ${ }^{c}$ & Not found ${ }^{c}$ \\
\hline
\end{tabular}

a Clidemia hirta is the species cited as being in use by traditional peoples of the Peruvian Amazon [38]

b Fruit and trunk bark macerates and infusions of these Xylopia spp. are used as anti-malarials: Xylopia aethiopica, Xylopia aromatica, Xylopia brasiliensis, Xylopia emarginata, Xylopia frutescens, Xylopia grandiflora, Xylopia hypolampra, Xylopia longifolia, Xylopia parviflora, Xylopia phloiodora, Xylopia staudtii, Xylopia xylopioides [30, $58,80-85,125,126]$

c These Zanthoxylum spp. are used as anti-malarials: Zanthoxylum armatum, Zanthoxylum caribaem, Zanthoxylum chalybeum, Zanthoxylum chiloperone, Zanthoxylum gilletii, Zanthoxylum hermaphroditum, Zanthoxylum leprieurii, Zanthoxylum pentandrum, Zanthoxylum perrottetti, Zanthoxylum rhoifolium, Zanthoxylum rubescens, Zanthoxylum tingoassuiba, Zanthoxylum tsihanimposa, Zanthoxylum usambarense, Zanthoxylum zanthoxyloides. Leaf, fruit, trunk bark and root bark decoctions are used $[33,58,59,84,85,100-105,107-110,127-129]$

a Soxhlet apparatus $(3 \times 6 \mathrm{~h})$. Extraction solvents were removed by rotary evaporation under vacuum using mild bath temperatures. Crude extracts were transferred to broad-mouthed vials and further evaporated in a $45-50{ }^{\circ} \mathrm{C}$ sand bath in a fume hood. After total evaporation, extracts were frozen at $-20{ }^{\circ} \mathrm{C}$, freeze-dried and weighed.

\section{In vitro culture of Plasmodium falciparum}

Chloroquine-resistant (CQR) Plasmodium falciparum W2 clone and K1 strain were used for in vitro antiplasmodial studies. The Trager and Jensen [42] in vitro culture technique was used with modifications [17]. Parasites were cultivated in type $\mathrm{A}^{+}$erythrocytes and culture medium (Roswell Park Memorial Institute or RPMI-1640) enriched with $10 \%$ human serum (complete medium) and maintained at $37{ }^{\circ} \mathrm{C}$ under an atmosphere of $5 \%$ carbon dioxide, $5 \%$ oxygen and $90 \%$ nitrogen.

Monitoring of parasite growth was performed every $24 \mathrm{~h}$ during the daily refreshing of culture medium. Parasitaemia was calculated as a percentage based on the viable parasitic forms observed by counting at least 2000 erythrocytes.

\section{Screening for in vitro antiplasmodial activity against Plasmodium falciparum K1 strain}

Parasite quantification by optical microscopy is a traditional and reliable technique in the performance of in vitro antiplasmodial assays [43]. In vitro antiplasmodial screening was performed according to a previously published procedure [17]. Each extract $(1.0 \mathrm{mg})$ was dissolved in dimethyl sulfoxide (DMSO) to provide a stock solution $(5.0 \mathrm{mg} / \mathrm{mL})$. Test solutions of each extract were prepared by diluting stock solution in RPMI-1640 culture medium and $20 \mu \mathrm{L}$ of each test solution were introduced into the wells of a 96-well plate. Then, a suspension of sorbitol-synchronized, parasitized red blood cells (pRBCs) [44] was adjusted to $1 \%$ parasitaemia and $3 \%$ haematocrit in complete medium and added $(180 \mu \mathrm{L} /$ well $)$. Screening of extracts was performed at final (well) concentrations of 50 and $5.0 \mu \mathrm{g} / \mathrm{mL}$. Negative controls were prepared with a suspension of $\mathrm{pRBCs}$ and $1 \%$ DMSO. Chloroquine was used as positive control. Test plates were incubated at $37{ }^{\circ} \mathrm{C}$ for $48 \mathrm{~h}$ under an atmosphere of $5 \%$ oxygen, $5 \%$ carbon dioxide and $90 \%$ nitrogen. After this period, thin blood smears of the contents of each well were stained with Panótico ${ }^{\circledR}$ (Laborclin, Pinhais, Paraná, Brazil) for evaluation of the parasitaemia using an optical microscope. The parasitaemia was expressed as a percentage of the viable erythrocytic parasite forms observed in 2000 RBCs. Parasite inhibition was expressed as a percentage of the growth of untreated (negative) controls. All assays were performed in triplicate [45]. Extracts that inhibited parasite growth by $\geq 80 \%$ at concentrations of $50 \mu \mathrm{g} / \mathrm{mL}$ 
were further evaluated using the procedure described below.

\section{In vitro antiplasmodial activity assessed by anti-HRPII ELISA}

Plasmodium falciparum histidine-rich protein II (HRPII) may be quantified as an indicator of cell growth through the enzyme-linked immunosorbent assay (ELISA)-sandwich technique [46-48]. This technique has been applied to the screening of a variety of crude plant extracts and fractions [49-52] and is a valid method for the screening of plant extracts providing similar $\mathrm{IC}_{50}$ values to traditional methods $[49,50]$.

Extracts exhibiting anti-malarial potential in the screening procedure described above against $P$. falciparum $\mathrm{K} 1$ strain were further evaluated to determine the concentrations that inhibit $50 \%$ of parasite growth $\left(\mathrm{IC}_{50}\right)$ using histidine rich protein II antibody (anti-HRPII) ELISA [47] with slight modifications [49]. Briefly, each extract was dissolved in DMSO using an ultrasound bath to form stock solutions $(10 \mathrm{mg} / \mathrm{mL})$. Each stock solution was serially diluted in culture medium to provide seven dilute samples. Each dilute sample $(20 \mu \mathrm{L})$ was applied to a 96-well test plate in triplicate. A suspension of sorbitolsynchronized pRBCs was adjusted to $0.05 \%$ parasitaemia and $1.5 \%$ haematocrit and placed in 96-well plates containing the test and control drugs providing final (in well) extract concentrations of $100-0.13 \mu \mathrm{g} / \mathrm{mL}$. The plates were incubated for $72 \mathrm{~h}$. After $24 \mathrm{~h}$, the contents of the six control wells (parasites in drug-free medium) were harvested in microtubes and frozen for later use to further exclude the background value (i.e., the production of HRPII during the first $24 \mathrm{~h}$ of incubation) by subtracting the average value obtained from these wells from that of the wells containing the test and control drugs. After $72 \mathrm{~h}$ of incubation, the plates were frozen and thawed twice to lyse the erythrocytes.

To perform the test, a clean plate (Maxysorp, Nunc, Denmark) was first coated with $100 \mu \mathrm{L}$ of the primary antibody anti-HRPII (MPFM ICLLAB-55A ${ }^{\circledR}$, Stuart, FL, USA) at $1.0 \mu \mathrm{g} / \mathrm{mL}$. Following overnight incubation at $4{ }^{\circ} \mathrm{C}$, the antibody solution was discarded and replaced with $200 \mu \mathrm{L} /$ well of $2 \%$ PBS-BSA (phosphate buffered saline and bovine serum albumin, Sigma-Aldrich) blocking solution. Following a new incubation at room temperature for $2 \mathrm{~h}$, the plate was washed with Tween 20 at $0.05 \%$ in PBS (PBS-T). Then, each pre-treated well received $100 \mu \mathrm{L}$ of $P$. falciparum parasite culture (as described above), which was pre-haemolyzed by freeze-thawing at $-70{ }^{\circ} \mathrm{C}$. In each test, two haemolyzed control sets of six wells each were used; one containing the $24 \mathrm{~h}$ cultures (background), the other with the $72 \mathrm{~h}$ parasite cultures. After incubation for $1 \mathrm{~h}$ at room temperature, the plate was again washed with PBS-T, incubated with $100 \mu \mathrm{L} /$ well of the secondary antibody (MPFG55P ICLLAB ${ }^{\circledR}$, Stuart, FL, USA), diluted 1:5000 times, and again incubated for $1 \mathrm{~h}$ at room temperature. After more washes with PBS-T, each well received $100 \mu \mathrm{L}$ of $3,3^{\prime}, 5,5^{\prime}$-tetramethylbenzidine (TMB) chromogen (KPL, Gaithersburg, MD, USA) and was incubated for $10 \mathrm{~min}$ at room temperature in the dark. The reaction was stopped with $50 \mu \mathrm{L} /$ well of $1 \mathrm{M}$ sulfuric acid and the absorbance was immediately read at $450 \mathrm{~nm}$ on a spectrophotometer (SpectraMax ${ }^{\circledR}$ 340PC384, Molecular Devices, Sunnyvale, CA, USA). Three separate experimental determinations were performed and the average readings were plotted and the $\mathrm{IC}_{50}$ values were determined from the plots.

\section{Screening for in vitro cytotoxicity (cell viability test)}

The cytotoxicity of extracts was evaluated in vitro against one non-neoplastic cell line (MRC-5-human fibroblast) purchased from the American Type Culture Collection (ATCC) and two melanoma cell lines (SK-MEL-19 and SK-MEL-28) donated by Dr. María S Soengas (CNIO, Madrid, Spain). The cells were cultivated in 96-well plates $\left(0.5 \times 10^{4}\right.$ cells per well $)$ and then were treated with extract in DMSO at a single concentration $(50 \mu \mathrm{g} / \mathrm{mL})$ over $72 \mathrm{~h}$. The Alamar Blue ${ }^{\mathrm{TM}}$ assay was performed after $72 \mathrm{~h}$ following a standard procedure [53].

\section{Murine macrophage culture}

J774 cells (murine macrophages) were obtained from the Cell Bank of Rio de Janeiro, Brazil and were maintained in Dulbecco's Modified Eagle Medium (DMEM), which was supplemented with $10 \%$ fetal bovine serum (FBS), penicillin $(100 \mathrm{U} / \mathrm{mL})$ and streptomycin $(100 \mathrm{U} / \mathrm{mL})$. The cells were incubated at $37^{\circ} \mathrm{C}$ in a humidified atmosphere containing $5 \%$ of $\mathrm{CO}_{2}$.

\section{Determination of in vitro toxicity against murine macrophages (cell viability test)}

The cytotoxicity was determined by the Alamar Blue method as described by Nakayama and co-workers [54]. Briefly, adherent cells $\left(5 \times 10^{3}\right.$ cells/well $)$ were grown in 96-well tissue culture plates and exposed to extracts $(1.56-200 \mu \mathrm{g} / \mathrm{mL})$ for $48 \mathrm{~h}$. After incubation, Alamar Blue solution $(10 \mu \mathrm{L}$ of $0.4 \%$ Alamar Blue (resazurin) in water) was added and the cells were incubated for $3 \mathrm{~h}$ at $37{ }^{\circ} \mathrm{C}$. Fluorescence was measured (excitation at $545 \mathrm{~nm}$ and emission at $595 \mathrm{~nm}$ ) and expressed as a percentage of the cells in the control after background fluorescence was subtracted. Doxorubicin was used as a positive control of cell death. The assays were performed in triplicate. The $\mathrm{IC}_{50}$ values and their $95 \%$ confidence intervals $(95 \% \mathrm{CI})$ were obtained by non-linear regression using the Graphpad program (Intuitive software for science, San Diego, CA, USA). 


\section{Animals and ethical approval}

Adult BALB/c mice ( $25 \pm 3 \mathrm{~g}$ weight) were used for the in vivo anti-malarial tests and received water and food ad libitum. In vivo tests were performed following the Guidelines for Ethical Conduct in The Care and Use of Animals of the National Institute for Amazon Research (INPA). This work was authorized by INPA's Commission for the Ethical Use of Animals (CEUA 029/2013).

\section{In vivo anti-malarial test}

Three extracts exhibiting in vitro antiplasmodial activity in the above assay were tested for oral activity against the Plasmodium berghei NK65 strain in mice with blood-induced infections maintained by successive passages from mouse to mouse. The protocol used was based on the Peters [55] four-day suppressive test with slight modifications [21]. In each experiment, the animals were divided into groups of five individuals and treated for four successive days with extract $(250 \mathrm{mg} / \mathrm{kg} /$ day $)$ starting $24 \mathrm{~h}$ after inoculation with $P$. berghei $\left(1 \times 10^{5}\right.$ parasitized erythrocytes/animal $)$. In each experiment, positive and negative control groups received chloroquine $(10 \mathrm{mg} / \mathrm{kg} /$ day $)$ and vehicle $(2 \%$ DMSO), respectively. Each sample was tested in at least two independent experiments. On days 5 and 7 after infection, blood smears from all mice were prepared, stained with the Panótico ${ }^{\circledR}$ system (Laborclin, Pinhais, Paraná, Brazil) and examined under a microscope. The parasitaemia was determined in blood smears that were characterized by random counting of 2000-4000 erythrocytes when parasitaemia was low ( $\leq 10 \%$ ) or up to 1000 erythrocytes when parasitaemia was higher. Mortality was monitored daily in all groups during a period of 4 weeks after inoculation.

\section{Results}

In vitro antiplasmodial activity, cytotoxicity and selectivity of extracts

A total of 69 chloroform, ethanol, methanol, and water extracts from different parts of the 11 plant species were prepared. Screening against $P$. falciparum K1 strain revealed 32 extracts that exhibited antiplasmodial potential $\left(\mathrm{IC}_{50} \leq 50 \mu \mathrm{g} / \mathrm{mL}\right)$. These extracts were further evaluated in vitro against the CQR P. falciparum W2 clone to establish accurate $\mathrm{IC}_{50}$ values. The in vitro $\mathrm{IC}_{50}$ values of plant extracts are shown in Table 2. Extracts exhibiting $\mathrm{IC}_{50}$ values $\leq 10 \mu \mathrm{g} / \mathrm{mL}$ were considered to be active. Those exhibiting $\mathrm{IC}_{50}$ values in the range 10 to $\leq 25 \mu \mathrm{g} /$ $\mathrm{mL}$ were considered moderately active. Extracts exhibiting $\mathrm{IC}_{50}$ values $>25 \mu \mathrm{g} / \mathrm{mL}$ were considered inactive. Andropogon leucostachyus aerial part methanol extracts, Croton cajucara red variety leaf chloroform extracts, Miconia nervosa leaf methanol extracts and Xylopia amazonica leaf chloroform and branch ethanol extracts were the most active ( $7 \%$ of all extracts). Moderate activity ( $22 \%$ of all extracts) was observed for Clidemia bullosa DC branch chloroform extract and decoction, Croton cajucara white variety leaf chloroform and ethanol and bark ethanol extracts, Croton cajucara red variety leaf ethanol extract, Miconia nervosa bark and leaf chloroform extracts and leaf decoction, Paullinia cupana fruit and branch chloroform extracts, Xylopia amazonica leaf decoction and branch chloroform extract and Zanthoxylum djalma-batistae leaf decoction and branch chloroform extract. Seventy-one per cent of the extracts were inactive. All extracts prepared from Anacardium occidentale, Derris floribunda, Parkia nitida and Stigmaphyllon sinuatum were inactive in vitro against $P$. falciparum as were Croton cajucara red variety bark and Paullina cupana leaf extracts.

During initial screening, those extracts that reduced in vitro cell viability to less than $10 \%$ of that of untreated controls after $72 \mathrm{~h}$ were considered to be cytotoxic. Thus, only Paullina cupana branch chloroform extract was toxic to MRC-5 cells (6.8 \% viability after $72 \mathrm{~h}$ ). This same extract was toxic to SK-MEL-19 and SK-MEL-28 melanoma cells (7.3 and $6.6 \%$ viability, respectively). Croton cajucara red variety leaf ethanol extract was also toxic to SK-MEL-28 cells. All other extracts did not significantly inhibit proliferation of MRC-5, SK-MEL-19 or SKMEL-28 cells (viability $>50 \%$ at concentrations of $50 \mu \mathrm{g} /$ $\mathrm{mL})$.

Thirty extracts were evaluated for in vitro toxicity against murine macrophages to establish $\mathrm{IC}_{50}$ values and selectivity parameters (Table 2). Twenty-three extracts were essentially non-toxic to murine macrophages $\left(\mathrm{IC}_{50}\right.$ values $>50 \mu \mathrm{g} / \mathrm{mL}$ ). However, Xylopia amazonica branch ethanol and Zanthoxylum djalma-batistae branch chloroform extracts $\left(\mathrm{IC}_{50}=6.9\right.$ and $24.7 \mu \mathrm{g} / \mathrm{mL}$, respectively) exhibited significant cytotoxicity $\left(\mathrm{IC}_{50}<25 \mu \mathrm{g} / \mathrm{mL}\right)$ to macrophages. Andropogon leucostachyus aerial part methanol extracts exhibited the greatest selectivity index (SI >28.2) (Table 2).

\section{In vivo activity of extracts}

Three extracts exhibiting in vitro antiplasmodial activity were assayed for in vivo anti-malarial activity and the results are presented in Table 3. Andropogon leucostachyus extract was the most active in vivo exhibiting $71 \%$ suppression of $P$. berghei parasitaemia on the fifth day. Xylopia amazonica leaf extracts exhibited 52 \% suppression on the fifth day of infection and low in vivo parasite suppression was observed for Croton cajucara red variety leaf extracts (Table 3).

\section{Discussion}

Several strategies are available for the discovery of new anti-malarial drugs. In vitro screening for inhibitory 
Table 2 In vitro median inhibitory concentrations $\left(\mathrm{IC}_{50}\right)$ against Plasmodium falciparum strains, toxicity to murine macrophages $\left(\mathrm{IC}_{50}\right)$ and selectivity indices $(\mathrm{SI})$ of plant extracts

\begin{tabular}{|c|c|c|c|c|c|c|}
\hline \multirow{2}{*}{$\begin{array}{l}\text { Plant species } \\
\text { Anacardium occidentale }\end{array}$} & \multirow{2}{*}{$\begin{array}{l}\text { Part } \\
\text { Bark }\end{array}$} & \multirow{2}{*}{$\begin{array}{l}\text { Extract } \\
\mathrm{CHCl}_{3}\end{array}$} & \multicolumn{2}{|c|}{$\begin{array}{l}\text { P. falciparum }{ }^{\mathrm{a}} \\
\mathrm{IC}_{50}, \mu \mathrm{g} / \mathrm{mL} \pm \mathrm{SD}^{\mathrm{b}}\end{array}$} & \multirow{2}{*}{$\begin{array}{l}\text { Macrophages } \\
\mathrm{IC}_{\mathbf{5 0}}, \boldsymbol{\mu g} / \mathrm{mL}(95 \% \mathrm{Cl}) \\
>200\end{array}$} & \multirow{2}{*}{$\begin{array}{l}\mathrm{SI}^{\mathbf{c}} \\
>5.5\end{array}$} \\
\hline & & & $36.6 \pm 17.7$ & 1 & & \\
\hline & & $\mathrm{EtOH}$ & $>50$ & 1 & - & - \\
\hline & & $\mathrm{H}_{2} \mathrm{O}(\mathrm{i})$ & $>50$ & । & - & - \\
\hline & Leaf & $\mathrm{CHCl}_{3}$ & $43.9 \pm 10.8$ & I & $>200$ & $>4.6$ \\
\hline & & $\mathrm{EtOH}$ & $>50$ & I & - & - \\
\hline & & $\mathrm{H}_{2} \mathrm{O}(\mathrm{i})$ & $45.0 \pm 5.0$ & 1 & $>200$ & $>4.4$ \\
\hline \multirow[t]{3}{*}{ Andropogon leucostachyus } & Aerial part & $\mathrm{CHCl}_{3}$ & $>50$ & I & - & - \\
\hline & & $\mathrm{H}_{2} \mathrm{O}(\mathrm{d})$ & $45.4 \pm 0.4$ & I & $>200$ & $>4.4$ \\
\hline & & $\mathrm{MeOH}$ & $7.1 \pm 3.3$ & A & $>200$ & $>28.2$ \\
\hline \multirow[t]{6}{*}{ Clidemia bullosa } & Leaf & $\mathrm{CHCl}_{3}$ & $>50$ & 1 & - & - \\
\hline & & $\mathrm{H}_{2} \mathrm{O}(\mathrm{d})$ & $26.2 \pm 3.1$ & 1 & $>200$ & $>7.6$ \\
\hline & & $\mathrm{MeOH}$ & $>50$ & । & - & - \\
\hline & Branch & $\mathrm{CHCl}_{3}$ & $13.5 \pm 2.7$ & MA & $>200$ & $>14.8$ \\
\hline & & $\mathrm{H}_{2} \mathrm{O}(\mathrm{d})$ & $21.2 \pm 4.0$ & MA & - & - \\
\hline & & $\mathrm{MeOH}$ & $>50$ & । & - & - \\
\hline \multirow[t]{6}{*}{ Croton cajucara (white variety-WV) } & Bark & $\mathrm{CHCl}_{3}$ & $29.1 \pm 6.3$ & 1 & $43.1(27.4-67.8)$ & 1.5 \\
\hline & & $\mathrm{EtOH}$ & $17.2 \pm 6.6$ & MA & $127(49.8-321)$ & 7.4 \\
\hline & & $\mathrm{H}_{2} \mathrm{O}(\mathrm{i})$ & $>50$ & । & - & - \\
\hline & Leaf & $\mathrm{CHCl}_{3}$ & $11.3 \pm 3.4$ & MA & $>200$ & $>17.7$ \\
\hline & & $\mathrm{EtOH}$ & $16.3 \pm 4.5$ & MA & $>200$ & $>12.3$ \\
\hline & & $\mathrm{H}_{2} \mathrm{O}(\mathrm{i})$ & $>50$ & । & - & - \\
\hline \multirow[t]{6}{*}{ Croton cajucara (red variety-RV) } & Bark & $\mathrm{CHCl}_{3}$ & $32.2 \pm 5.7$ & 1 & $>200$ & $>6.2$ \\
\hline & & $\mathrm{EtOH}$ & $>50$ & I & - & - \\
\hline & & $\mathrm{H}_{2} \mathrm{O}(\mathrm{i})$ & $>50$ & । & - & - \\
\hline & Leaf & $\mathrm{CHCl}_{3}$ & $6.4 \pm 1.2$ & A & $40.6(32.6-50.6)$ & 6.3 \\
\hline & & $\mathrm{EtOH}$ & $13.3 \pm 2.3$ & MA & $>200$ & $>15.0$ \\
\hline & & $\mathrm{H}_{2} \mathrm{O}(\mathrm{i})$ & $>50$ & । & - & - \\
\hline \multirow[t]{6}{*}{ Derris floribunda } & Bark & $\mathrm{CHCl}_{3}$ & $>50$ & I & - & - \\
\hline & & $\mathrm{H}_{2} \mathrm{O}(\mathrm{i})$ & $>50$ & 1 & - & - \\
\hline & & $\mathrm{MeOH}$ & $>50$ & 1 & - & - \\
\hline & Leaf & $\mathrm{CHCl}_{3}$ & $47.4 \pm 1.6$ & I & $>200$ & $>4.2$ \\
\hline & & $\mathrm{H}_{2} \mathrm{O}(\mathrm{i})$ & $27.5 \pm 7.5$ & 1 & - & - \\
\hline & & $\mathrm{MeOH}$ & $>50$ & I & - & - \\
\hline \multirow[t]{6}{*}{ Miconia nervosa } & Bark & $\mathrm{CHCl}_{3}$ & $13.3 \pm 2.0$ & MA & $46.6(43.1-50.4)$ & 3.5 \\
\hline & & $\mathrm{H}_{2} \mathrm{O}(\mathrm{d})$ & $>50$ & I & - & - \\
\hline & & $\mathrm{MeOH}$ & $>50$ & I & - & - \\
\hline & Leaf & $\mathrm{CHCl}_{3}$ & $12.4 \pm 4.1$ & MA & $70.6(62.7-79.7)$ & 5.7 \\
\hline & & $\mathrm{H}_{2} \mathrm{O}(\mathrm{d})$ & $10.2 \pm 2.5$ & MA & $>200$ & $>19.6$ \\
\hline & & $\mathrm{MeOH}$ & $9.9 \pm 3.2$ & A & $95.9(71.0-130)$ & 9.7 \\
\hline \multirow[t]{6}{*}{ Parkia nitida } & Bark & $\mathrm{CHCl}_{3}$ & $>50$ & I & - & - \\
\hline & & $\mathrm{H}_{2} \mathrm{O}(\mathrm{d})$ & $>50$ & I & - & - \\
\hline & & $\mathrm{MeOH}$ & $>50$ & 1 & - & - \\
\hline & Leaf & $\mathrm{CHCl}_{3}$ & $>50$ & I & - & - \\
\hline & & $\mathrm{H}_{2} \mathrm{O}(\mathrm{d})$ & $>50$ & 1 & - & - \\
\hline & & $\mathrm{MeOH}$ & $>50$ & 1 & - & - \\
\hline \multirow[t]{3}{*}{ Paullinia cupana } & Leaf & $\mathrm{CHCl}_{3}$ & $>50$ & 1 & - & - \\
\hline & & $\mathrm{H}_{2} \mathrm{O}(\mathrm{i})$ & $>50$ & I & - & - \\
\hline & & $\mathrm{MeOH}$ & $>50$ & I & - & - \\
\hline
\end{tabular}


Table 2 continued

\begin{tabular}{|c|c|c|c|c|c|c|}
\hline \multirow[t]{2}{*}{ Plant species } & \multirow{2}{*}{$\begin{array}{l}\text { Part } \\
\text { Fruit }\end{array}$} & \multirow{2}{*}{$\begin{array}{l}\text { Extract } \\
\mathrm{CHCl}_{3}\end{array}$} & \multicolumn{2}{|c|}{$\begin{array}{l}\text { P. falciparum } \\
\mathrm{IC}_{50}, \mu \mathrm{g} / \mathrm{mL} \pm \mathrm{SD}^{\mathrm{b}}\end{array}$} & \multirow{2}{*}{$\begin{array}{l}\text { Macrophages } \\
\mathrm{IC}_{\mathbf{5 0}}, \boldsymbol{\mu g} / \mathrm{mL}(95 \% \mathrm{Cl}) \\
>200\end{array}$} & \multirow{2}{*}{$\begin{array}{l}\mathbf{S I}^{\mathbf{c}} \\
>10.4\end{array}$} \\
\hline & & & $19.3 \pm 6.4$ & MA & & \\
\hline & & $\mathrm{H}_{2} \mathrm{O}(\mathrm{i})$ & $>50$ & I & - & - \\
\hline & & $\mathrm{MeOH}$ & $>50$ & 1 & - & - \\
\hline & Branch & $\mathrm{CHCl}_{3}$ & $19.3 \pm 5.5$ & MA & $62.9(53.9-73.4)$ & 3.3 \\
\hline & & $\mathrm{H}_{2} \mathrm{O}(\mathrm{i})$ & $>50$ & I & - & - \\
\hline & & $\mathrm{MeOH}$ & $>50$ & 1 & - & - \\
\hline \multirow[t]{3}{*}{ Stigmaphyllon sinuatum } & Leaf & $\mathrm{CHCl}_{3}$ & $>50$ & 1 & - & - \\
\hline & & $\mathrm{EtOH}$ & $>50$ & । & - & - \\
\hline & & $\mathrm{H}_{2} \mathrm{O}(\mathrm{i})$ & $>50$ & I & - & - \\
\hline \multirow[t]{6}{*}{ Xylopia amazonica } & Leaf & $\mathrm{CHCl}_{3}$ & $7.3 \pm 1.8$ & A & $33.9(29.6-38.9)$ & 4.6 \\
\hline & & $\mathrm{H}_{2} \mathrm{O}(\mathrm{d})$ & $10.5 \pm 3.3$ & MA & $>200$ & $>19.0$ \\
\hline & & $\mathrm{EtOH}$ & $>50$ & I & - & - \\
\hline & Branch & $\mathrm{CHCl}_{3}$ & $19.5 \pm 3.1$ & MA & $29.2(19.6-43.5)$ & 1.5 \\
\hline & & $\mathrm{H}_{2} \mathrm{O}(\mathrm{d})$ & $>50$ & 1 & - & - \\
\hline & & $\mathrm{EtOH}$ & $9.8 \pm 1.8$ & $A$ & $6.9(0.4-12.1)$ & 0.7 \\
\hline \multirow[t]{6}{*}{ Zanthoxylum djalma-batistae } & Leaf & $\mathrm{CHCl}_{3}$ & $40.2 \pm 3.2$ & 1 & $>200$ & $>5.0$ \\
\hline & & $\mathrm{H}_{2} \mathrm{O}(\mathrm{i})$ & $15.6 \pm 2.9$ & MA & $>200$ & $>12.8$ \\
\hline & & $\mathrm{MeOH}$ & $>50$ & I & - & - \\
\hline & Branch & $\mathrm{CHCl}_{3}$ & $17.4 \pm 1.3$ & MA & $24.7(18.6-32.9)$ & 1.4 \\
\hline & & $\mathrm{H}_{2} \mathrm{O}(\mathrm{i})$ & $32.5 \pm 7.9$ & I & $>200$ & $>6.2$ \\
\hline & & $\mathrm{MeOH}$ & $21.8 \pm 3.7$ & I & $>200$ & $>9.2$ \\
\hline \multirow[t]{3}{*}{ Controls } & DMSO & & - & I & - & - \\
\hline & Chloroq & sphate & $0.23 \pm 0.03$ & $A$ & - & - \\
\hline & Doxoruk & & - & - & $0.63(0.59-0.68)$ & - \\
\hline
\end{tabular}

EtOH ethanol, $\mathrm{MeOH}$ methanol, $\mathrm{H}_{2} \mathrm{O}(\mathrm{i})$ infusion, $\mathrm{H}_{2} \mathrm{O}(\mathrm{d})$ decoction, $\mathrm{SD}$ standard deviation, $95 \% \mathrm{Cl} 95 \%$ confidence interval, - not evaluated, not determined

a All extracts were screened at 50 and $5 \mathrm{mg} / \mathrm{mL}$ against $P$. falciparum $\mathrm{K} 1$ strain using optical microscopy in three separate experiments. Accurate $\mathrm{IC}_{50}$ values were determined using seven concentrations of extract against $P$. falciparum W2 strain using the HRP2-ELISA method

b Antiplasmodial effect based on $\mathrm{IC}_{50}$ : $A$ active $\left(\mathrm{IC}_{50} \leq 10 \mu \mathrm{g} / \mathrm{mL}\right), M A$ moderately active $\left(10<\mathrm{IC}{ }_{50} \leq 25 \mu \mathrm{g} / \mathrm{mL}\right)$ and $/ \mathrm{inactive}\left(\mathrm{IC} C_{50}>25 \mu \mathrm{g} / \mathrm{mL}\right)$

c $\mathrm{SI}=\mathrm{IC}_{50 \text { (murine macrophages) }} / \mathrm{IC} \mathrm{C}_{5 \text { (P. falciparum) }}$

Table 3 Parasitemia suppression versus untreated controls and survival in mice infected with Plasmodium berghei after oral administration of plant extracts for four days

\begin{tabular}{|c|c|c|c|c|c|c|}
\hline \multirow[t]{2}{*}{ Plant } & \multirow[t]{2}{*}{ Part } & \multirow[t]{2}{*}{ Extract } & \multirow[t]{2}{*}{ Dose (mg/kg/day) } & \multicolumn{2}{|c|}{$\%$ parasite \pm SD (\% suppression) } & \multirow{2}{*}{$\begin{array}{l}\text { Avg. survival } \pm S D \\
\text { (days) }\end{array}$} \\
\hline & & & & Day 5 & Day 7 & \\
\hline $\begin{array}{l}\text { Andropogon leucos- } \\
\text { tachyus }\end{array}$ & Aerial part & $\mathrm{MeOH}$ & 250 & $0.49 \pm 0.10(71)$ & $1.12 \pm 0.07(48)$ & $19 \pm 2$ \\
\hline Croton cajucara RV & Leaf & $\mathrm{CHCl}_{3}$ & 250 & $1.4 \pm 0.27(19)$ & $2.2 \pm 0.15(0)$ & $23 \pm 3$ \\
\hline Xylopia amazonica & Leaf & $\mathrm{CHCl}_{3}$ & 250 & $0.82 \pm 0.22(52)$ & $1.87 \pm 0.26(11)$ & $20 \pm 2$ \\
\hline \multirow[t]{2}{*}{ Controls } & & Chloroquine diphosphate & 10 & $0.15 \pm 0.04(91)$ & $0.14 \pm 0.04$ & $31 \pm 4$ \\
\hline & & Vehicle (Blank) & & $1.74 \pm 0.21$ & $2.12 \pm 0.31$ & $22 \pm 1$ \\
\hline
\end{tabular}

$\mathrm{CHCl}_{3}$ chloroform, $\mathrm{MeOH}$ methanol, $\mathrm{SD}$ standard deviation

activity against $P$. falciparum and identification of traditionally used plant extracts exhibiting $\mathrm{IC}_{50}$ values less than $10 \mu \mathrm{g} / \mathrm{mL}$ are important first steps in the search for new anti-malarial plant extracts. Similar approaches have led to the identification of extracts for chemical composition studies and the discovery of potent plant natural products, such as artemisinin and nimbolide [56, 57]. 
In traditional medicine, Andropogon leucostachyus whole plant decoctions are ingested as a treatment for malaria [58]. In this work, Andropogon leucostachyus aerial part decoctions exhibited low in vitro activity. Methanol extraction was the most efficient process for concentrating the in vitro $\left(\mathrm{IC}_{50}=7.1 \pm 3.3 \mu \mathrm{g} / \mathrm{mL}\right.$ against $P$. falciparum) anti-malarial activity and selectivity of Andropogon leucostachyus. In fact, Andropogon leucostachyus aerial part methanol extracts exhibited the highest selectivity index ( $\mathrm{SI}=28.2)$ of all extracts evaluated herein. The concentration of anti-malarial components in these extracts is further attested to by the in vivo result (71\% suppression of $P$. berghei). Interestingly, the leaf decoctions of a related species, Andropogon schoenanthus, are ingested (with large amounts of sugar) to treat malaria fevers. Inhalation of the vapours from the boiling decoction is also used to treat malaria [59]. Very little is known about the chemical composition of Andropogon leucostachyus. C-glycosylflavones, the $O$-methyl flavone tricin and the flavanol luteoforol have been described in the leaves of Andropogon leucostachyus [60]. No anti-malarial activity has been reported for these flavonoids in the literature. In silico docking studies have explored the potential of tricin as a parasite dihydrofolate reductase inhibitor however it was found to interact less favorably with this enzyme than other compounds [61].

Croton cajucara is a cultivated plant that has red and white varieties (a reference to the coloration of young leaves). It occurs in Bolivia, Brazil, Guyana and Venezuela. Croton cajucara trunk bark or leaf infusions are used in traditional medicine to treat malaria according to many sources [62-68]. Herein, Croton cajucara extracts of both varieties were active or moderately active in vitro. Red variety leaf chloroform extract exhibited the highest in vitro inhibitory activity against $P$. falciparum W2 clone $\left(\mathrm{IC}_{50}=6.4 \pm 1.2 \mu \mathrm{g} / \mathrm{mL}\right)$. This extract was further evaluated for in vivo oral activity against $P$. berghei in infected mice, however, it exhibited low in vivo anti-malarial activity (Table 3). Synergism among the bioactive components that comprise an extract could explain in vitro antiplasmodial activity however in vivo these chemical constituents may have a lessened effect due to their metabolism (biotransformation), low bioavailability and physiological factors in the host [69].

A number of Croton species have been found in previous studies to exhibit significant in vitro and in vivo anti-malarial activity. Croton leptostachyus aerial part ethanol extracts exhibited high in vitro activity against $P$. falciparum $\left(\mathrm{IC}_{50}=2.1 \pm 0.2 \mu \mathrm{g} / \mathrm{mL}\right)$, however, this extract was toxic to mice [30]. Several Croton zambesicus root extracts and fractions exhibited in vivo anti-malarial activity (79-86 \% parasitaemia suppression at doses of $27-81 \mathrm{mg} / \mathrm{kg} /$ day) against $P$. berghei in rodents [70].
Also, Croton mubango stem bark water extracts inhibited P. falciparum in vitro $\left(\mathrm{IC}_{50}=3.2 \mu \mathrm{g} / \mathrm{mL}\right)$ and suppressed P. berghei ANKA by $77 \%$ at oral doses of $200 \mathrm{mg} / \mathrm{kg} /$ day [71]. Significant dose dependency in the suppression of P. berghei in mice has been observed for Croton macrostachyus water and methanol extracts (200, 400 and $600 \mathrm{mg} / \mathrm{kg}$ ) [72]. Similar results were obtained for crude extracts and chloroform, methanol and water fractions of this same species wherein the chloroform fraction exhibited the best result [73].

A number of antiplasmodial diterpenes have been isolated from Croton species. 8,9-secokaurane was isolated from Croton kongensis and inhibited P. falciparum K1 strain $\left(\mathrm{IC}_{50}=1-2.8 \mu \mathrm{g} / \mathrm{mL}\right)$ [74] and geranyl geraniol was isolated from Croton lobatus extracts and inhibited $P$. falciparum $\left(\mathrm{IC}_{50}=3.7 \mu \mathrm{M}\right)[64]$. Steenkrotin A, was isolated from Croton steenkampianus leaf ethanol extracts and exhibited $\mathrm{IC}_{50}=15.8,>30,9.4$ and $9.1 \mu \mathrm{M}$ against P. falciparum D10, D6, Dd2 and W2 clones, respectively [66].

Miconia nervosa is used traditionally in the treatment of malaria as a decoction as are Miconia laevigata and Miconia willdenowii [58, 62, 75, 76]. Herein, Miconia nervosa leaf extracts exhibited in vitro activity against $P$. falciparum W2 clone. No previous report on the antiplasmodial activity of extracts of a species of Miconia is available in the literature. Interestingly, other species from this genus, Miconia fallax and Miconia stenostachya, are known to produce triterpene compounds that inhibit the protozoa Trypanosoma cruzi [77].

Xylopia amazonica was revealed herein as a plant whose crude extracts have anti-malarial potential. Two of its extracts were active and a third was moderately active. Among these, the leaf chloroform extracts exhibited good in vitro antiplasmodial activity $\left(\mathrm{IC}_{50}=7.3 \mu \mathrm{g} / \mathrm{mL}\right)$ and no significant toxicity to human fibroblasts or melanoma cells was observed. Notwithstanding, these extracts exhibited low selectivity ( $\mathrm{SI}=4.6)$, which is an indication that chloroform extraction concentrates specific toxicity to $P$. falciparum and murine macrophages. Interestingly, cytotoxicity has been observed for the extracts of Xylopia aromatica trunk chloroform-methanol extracts against NCI-H460, KM-12 and SF-268 cell lines and cancer cell line RPMI-8226 [78]. Also, Xylopia aromatica wood hexane extracts exhibited $\mathrm{IC}_{50}=5-20 \mu \mathrm{g} / \mathrm{mL}$ against several tumour cell lines (SF-295, HCT-8, MDA-MB-435 and HL-60) [79].

In several countries, the macerated or infused fruit and/or trunk bark of at least a dozen Xylopia species are used to treat malaria [30, 58, 80-85]. The extracts of several of these plants exhibit in vitro antiplasmodial activity according to previous studies. Xylopia phloiodora and Xylopia aethiopica extracts inhibit P. falciparum in vitro 
$\left(\mathrm{IC}_{50}=18 \mu \mathrm{g} / \mathrm{mL}\right)$ [80]. Xylopia emarginata leaf [81], root bark, trunk bark and wood [86] extracts exhibit $\mathrm{IC}_{50}=3-11 \mu \mathrm{g} / \mathrm{mL}$ against $P$. falciparum Palo Alto or FcB1 strains. The ethanol extract of the aerial parts of Xylopia aromatica strongly inhibit P. falciparum in vitro $\left(\mathrm{IC}_{50}<1 \mu \mathrm{g} / \mathrm{mL}\right)$ [30] while root, root bark and trunk bark hexane extracts do so to a lesser extent $\left(\mathrm{IC}_{50}=4.7,6.8\right.$ and $15.3 \mu \mathrm{g} / \mathrm{mL}$, respectively) against $P$. falciparum FcB1 strain [86].

Besides the in vitro antiplasmodial activity observed, Xylopia amazonica leaf chloroform extracts administered orally were able to suppress (52\%) P. berghei in mice at daily doses of $250 \mathrm{mg} / \mathrm{kg}$ herein. For a related species, Xylopia aromatica, it was found that aerial part ethanol extracts strongly inhibited $P$. falciparum in vitro $\left(\mathrm{IC}_{50}\right.$ $<1 \mu \mathrm{g} / \mathrm{mL}$ ) but were inactive in vivo [30].

Xylopia amazonica is known to produce kaurene diterpenes and aporphine alkaloids. From the wood and or bark, the diterpenes beyerene, ent-kauran-16 $\beta$-ol, ent-kaur-16-en-19-oic acid (kaurenoic acid) and 4-epikaurenoic acid have been isolated $[87,88]$ as have the aporphine alkaloids liriodenine, dicentrinone [87], oxoglaucine, (+)-glaucine, lirioferine and (+)-laurotetanine $[87,88]$.

Importantly, several of the natural products isolated from Xylopia amazonica have been isolated from other plant species and found to exhibit in vitro antiplasmodial activity. Thus, (+)-laurotetanine (isolated from Nectandra salicifolia) exhibited $\mathrm{IC}_{50}$ values of 3.9 and $2.5 \mu \mathrm{g} / \mathrm{mL}$ against $P$. falciparum D6 and W2 parasite clones [89]. Dicentrinone from another species inhibited P. falciparum $\mathrm{K} 1$ strain $\left(\mathrm{IC}_{50}=1.2 \mu \mathrm{g} / \mathrm{mL}\right)$ [90]. Liriodenine inhibited $P$. falciparum D6, D10 and W2 clones $\left(\mathrm{IC}_{50}=1.3,4.1\right.$ and $2.4 \mu \mathrm{g} / \mathrm{mL}$, respectively) [91, 92] whereas oxoglaucine exhibited low activity [92]. The diterpene ent-kaur-16-en-19-oic acid was not active against chloroquine-sensitive $P$. falciparum D10 clone $\left(\mathrm{IC}_{50}=31.8 \mu \mathrm{g} / \mathrm{mL}\right)$ [93].

Clidemia hirta known as soap bush or Koster's curse, is used as an anti-malarial among the traditional peoples of the Peruvian Amazon [38]. Herein, three Clidemia bullosa extracts exhibited moderate in vitro antiplasmodial activity. There is no information referring specifically to the traditional anti-malarial use of this species. However, Clidemia bullosa, Clidemia hirta and another species are closely related and occur together [94]. No information is available on the chemical composition of Clidemia bullosa, however, recent work on the chemical composition of the related species, Clidemia hirta, revealed the presence of hydrolysable tannins, derivatives of ellagic acid and the triterpene arjunolic acid [95].

Most Paullinia cupana (guaraná) extracts did not exhibit antiplasmodial activity. Bark and fruit chloroform extracts of this plant exhibited only moderate antiplasmodial activity. Guaraná extracts are widely consumed in the form of soft drinks and other beverages in Brazil. This plant is used in anti-malarial remedies in different locations in Latin America [58, 63, 96, 97]. In the branch bark, catechin and epicatechin have been detected [98]. These compounds may contribute, together with other compounds, to the moderate antiplasmodial properties observed [99].

Zanthoxylum djalma-batistae leaf infusion and branch chloroform extracts exhibited moderate antiplasmodial activity $\left(\mathrm{IC}_{50}=15.6 \pm 2.9\right.$ and $17.4 \pm 1.3 \mu \mathrm{g} / \mathrm{mL}$, respectively) herein. More than a dozen Zanthoxylum species are reported to be used as anti-malarials in several countries [33, 59, 84, 85, 100-110] and antiplasmodial activity has been observed for extracts of these plants. Thus, Zanthoxylum chalybeum extracts inhibit P. falciparum in vitro $\left(\mathrm{IC}_{50}<10 \mu \mathrm{g} / \mathrm{mL}\right)[100,102,104,107]$. Also, Zanthoxylum usambarense trunk bark and trunk wood methanol extracts inhibit P. falciparum NF54 strain ( $\mathrm{IC}_{50}$ $<5 \mu \mathrm{g} / \mathrm{mL}$ ) [103].

There is no information on the chemical composition of Zanthoxylum djalma-batistae. Antiplasmodial benzophenanthridine alkaloids such as nitidine are found in Zanthoxylum and other Rutaceae species. Nitidine has been isolated from Zanthoxylum usambarense and Zanthoxylum rhoifolium $[33,111]$ and exhibits submicromolar $\mathrm{IC}_{50}$ values against $P$. falciparum $[33,112]$.

Use of cashew tree (Anacardium occidentale) trunk bark, leaves or fruit in the treatment of malaria symptoms is practiced by traditional peoples in Brazil, Colombia, Nigeria and Peru [58, 68, 82, 96, 113]. Anacardium occidentale leaves are reported to contain anacardic acid and cardol [58, 114]. Anacardic acid is believed to alter parasite gene expression and inhibit parasite development in vitro through enzyme inhibition. In vitro this compound was inactive $\left(\mathrm{IC}_{50}=30.4-34.8 \mu \mathrm{M}\right)$ against a number of $P$. falciparum strains (3D7, D10, 7 G8 and Dd2) [115]. Anacardium occidentale extracts were in general inactive in the present study.

Surprisingly, Derris floribunda extracts were inactive herein despite the traditional use of timbó as an anti-malarial and previous reports on the antiplasmodial activity of Derris species. Derris amazonica extracts have been previously shown to inhibit P. falciparum F32 strain in vitro $\left(\mathrm{IC}_{50}=3.2 \mu \mathrm{g} / \mathrm{mL}\right)$ [15] and lupifolin has been isolated from Derris trifoliata seed pod extracts and inhibits P. falciparum D6 and W2 strains $\left(\mathrm{IC}_{50}=2.6-\right.$ $3.7 \mu \mathrm{g} / \mathrm{mL}$ ) [116].

In animal models of malaria, large experimental variability of the results is associated with drug, parasite and host interactions. For ethical reasons, the numbers of animals used may not be increased to more accurately 
characterize the antiparasitic effects. Despite this low experimental reproducibility, the murine malaria model used herein is an important tool in anti-malarial drug discovery and development programmes.

Methods and criteria vary among research groups that investigate the anti-malarial potential of plants using rodent models. Extract doses of $300-650 \mathrm{mg} / \mathrm{kg} /$ day providing 47.0-84.5\% parasitaemia suppressions have been considered evidence of important anti-malarial activity [22, 117-119]. Also, extracts providing $>60 \%$ suppression of parasitaemia at oral doses of $100-250 \mathrm{mg} /$ $\mathrm{kg} /$ day in the rodent model have been deemed active or highly active and suppression $>30 \%$ at these doses has been deemed moderate activity [120-123]. In the present work, oral doses of $250 \mathrm{mg}$ of plant extract per $\mathrm{kg}$ of body weight per day were used for evaluation of plant extracts and detection of relevant parasitaemia suppression $(>30 \%)$ on the fifth and or seventh days in the rodent model.

Herein, significant in vivo oral suppression of $P$. berghei by Andropogon leucostachyus and Xylopia amazonica extracts was demonstrated. Significant differences were not observed in the mean survival of animals treated with these extracts and untreated controls. This is true even for Andropogon leucostachyus extracts that were responsible for the largest suppression of parasitaemia observed. In the antiplasmodial extracts tested in vivo, the substances responsible for the suppressive activity may be present in low amounts and may exhibit short half-lives, thus not attaining the concentrations necessary for parasite suppression after the end of treatment. This together with rapid parasite metabolism may provide extract-treated and control groups exhibiting equal parasitaemia after only a few parasitic cycles, which for $P$. berghei is $24 \mathrm{~h}$ [124].

The in vitro inhibition of $P$. falciparum and selectivity demonstrated by several plant extracts and oral suppression of P. berghei by Andropogon leucostachyus and Xylopia amazonica extracts are significant findings. Bioguided fractionation of several of the extracts revealed in this study is now underway and should reveal the antimalarial chemical constituents of these plant species in the future.

\section{Conclusions}

Anti-malarial plants used traditionally in the Amazon and closely related species should be investigated for their anti-malarial potential to increase the knowledge of the useful flora of this region and provide active extracts. The identification of antiplasmodial and cytotoxic, traditionally used species can be useful as an initial step in pharmacological evaluations that can lead to more rational use. Furthermore, antiplasmodial plant extracts are the starting point for bioguided isolation of new antimalarial chemical constituents. It is always important to remember that among the clinically most relevant anti-malarials in use today are the synthetic quinolines (quinine analogues) and semi-synthetic artemisinin derivatives that comprise artemisinin-based combination therapy (ACT). Both of these classes of anti-malarials owe their origins to quinine and artemisinin discovered in traditionally used plants from the Peruvian Amazon region and China, respectively. Herein, $29 \%$ of the extracts studied were active or moderately active in vitro. The choice of plants studied was based on the traditional use of the species (ethnobotanic approach) or on the traditional use and or proven anti-malarial activity of plants and chemical constituents from the same genus (chemosystematic approach). The large number of active extracts attests to the importance of the accumulated traditional knowledge of anti-malarial plants in the Amazon region. The toxicity of a few extracts to tumour and non-tumour cells should serve as an alert that further toxicological evaluation of these plant extracts is necessary. The few extracts evaluated for in vivo anti-malarial activity were those that exhibited optimal in vitro antiplasmodial activity. However, in vivo evaluation of extracts that correspond to traditional plant remedies, generally infusions, decoctions and tinctures, and fractions enriched in antimalarial components is necessary as a means to more fully evaluate their anti-malarial potential. Bioguided chemical studies on the active extracts of Andropogon leucostachyus, Croton cajucara and Xylopia amazonica are now underway and should reveal the antiplasmodial components of these plants in the future.

\section{Authors' contributions}

RBSL collected plants, processed plant materials, carried out extractions, quantified blood smears for in vitro antiplasmodial screening and drafted the manuscript; LFRS carried out the in vitro antiplasmodial screenings using optical microscopy, performed the $\mathrm{IC}_{50}$ determinations with the immunoassay (with JPS and AUK), performed the in vivo antimalarial experiments and drafted the corresponding experimental, results and discussion sections of the manuscript; MRSM carried out in vitro screening of extracts; JQS performed the in vitro $\mathrm{IC}_{50}$ determinations using the immunoassay; NSP carried out in vivo anti-malarial experiments; ESL and MCV performed the screening of all extracts for in vitro cytotoxicity; JMPS researched and wrote sections of the discussion on chemistry and biological activity; APAB evaluated extracts in macrophage toxicity assays, revised sections of manuscript; RCNA processed plant materials, carried out extractions; FCMC cultivated, harvested and processed plant materials; JPC and AUK carried out (with LFRS) the in vitro immunoassays and critically reviewed and corrected the final manuscript; WPT participated in the coordination of the study; AMP conceived of the study, and participated in its design and coordination and drafted the manuscript. All authors read and approved the final manuscript.

\section{Author details}

${ }^{1}$ Laboratório de Princípios Ativos da Amazônia, Coordenação de Tecnologia e Inovação, Instituto Nacional de Pesquisas da Amazônia, Avenida André Araújo, 2936, Petrópolis, 69067-375 Manaus, Amazonas, Brazil. ${ }^{2}$ Programa de Pós-graduação em Biotecnologia, Universidade Federal do Amazonas, Avenida Gal. Rodrigo Otávio Jordão Ramos, 3000, Coroado I, Campus Universitário, Bloco M, Setor Sul, 69077-000 Manaus, Amazonas, Brazil. ${ }^{3}$ Centro Universitário 
do Norte, Rua Dez de Julho, 873, Centro, 69010-060 Manaus, Amazonas, Brazil. ${ }^{4}$ Escola Superior de Ciências da Saúde, Universidade Estadual do Amazonas, Avenida Carvalho Leal, 1777, Cachoeirinha, 69065-001 Manaus, Amazonas, Brazil. ${ }^{5}$ Faculdade de Ciências Farmacêuticas, Universidade Federal do Amazonas, Rua Comendador Alexandre Amorim, 330, Aparecida, 69103-000 Manaus, Amazonas, Brazil. ${ }^{6}$ Embrapa Amazônia Ocidental, Rodovia AM-010, Km 29 (Estrada Manaus/Itacoatiara), Caixa Postal 319, 69010-970 Manaus, Amazonas, Brazil. ${ }^{7}$ Centro de Pesquisas René Rachou, Fundação Oswaldo Cruz, Avenida Augusto de Lima, 1715, Barro Preto, 30190-002 Belo Horizonte, Minas Gerais, Brazil. ${ }^{8}$ Laboratório de Malária e Dengue, Coordenação de Sociedade, Ambiente e Saúde, Instituto Nacional de Pesquisas da Amazônia, Avenida André Araújo, 2936, Petrópolis, 69067-375 Manaus, Amazonas, Brazil.

\section{Acknowledgements}

The authors wish to recognize the support received from the Brazilian Council for Scientific and Technological Development (CNPq) through sub-network grants from the Brazilian Malaria and Bionorth Networks and from FAPEAM (PRONEX) and FAPEMIG (PRONEX). RBSL received a CNPq doctoral fellowship. AMP, AUK and ESL are CNPq productivity in research fellows. MRSM and LFRS were $\mathrm{PCI} / \mathrm{INPA} / \mathrm{MCT}$ fellows. MRSM and JPC are CNPq junior post-doctoral fellows. APAB is a CNPq DCR fellow.

\section{Competing interests}

The authors have declared that they have no competing interests.

Received: 19 May 2015 Accepted: 19 November 2015 Published online: 18 December 2015

\section{References}

1. Brandão MGL, Grandi TSM, Rocha EMM, Sawyer DR, Krettli AU. Survey of medicinal plants used as antimalarials in the Amazon. J Ethnopharmacol. 1992;36:175-82.

2. Breitbach UB, Niehues M, Lopes NP, Faria JEQ, Brandão MGL. Amazonian Brazilian medicinal plants described by C.F.P. von Martius in the 19th century. J Ethnopharmacol. 2013;147:180-9.

3. Adebayo JO, Krettli AU. Potential antimalarials from Nigerian plants: a review. J Ethnopharmacol. 2011;133:289-302.

4. Calderon LA, Silva-Jardim I, Zuliani JP, Silva AA, Ciancaglini P, Silva LH, et al. Amazonian biodiversity: a view of drug development for leishmaniasis and malaria. J Braz Chem Soc. 2009;20:1001-23.

5. Newman DJ, Cragg GM. Natural products as sources of new drugs over the 30 years from 1981 to 2010. J Nat Prod. 2012;75:311-35.

6. Schmidt TJ, Khalid SA, Romanha AJ, Alves TMA, Biavatti MW, Brun R, et al. The potential of secondary metabolites from plants as drugs or leads against protozoan neglected diseases-part I. Curr Med Chem. 2012;19:2128-75.

7. Schmidt TJ, Khalid SA, Romanha AJ, Alves TMA, Biavatti MW, Brun R, et al. The potential of secondary metabolites from plants as drugs or leads against protozoan neglected diseases-part II. Curr Med Chem. 2012;19:2176-228.

8. Kaur K, Jain M, Kaur T, Jain R. Antimalarials from nature. Bioorg Med Chem. 2009;17:3229-56.

9. Pohlit AM, Lima RBS, Frausin G, Silva LF, Lopes SC, Moraes CB, et al. Amazonian plant natural products: perspectives for discovery of new antimalarial drug leads. Molecules. 2013;18:9219-40.

10. Rangel TF. Amazonian extinction debts. Science. 2012;337:162-3.

11. Bascope M, Vila J, Erosa G, Sterner O. DNA affinity screening of plants from the Bolivian Amazonas rain Forest. Rev Bol Quim. 2010;27:100-3.

12. Bourdy G, Oporto P, Gimenez A, Deharo E. A search for natural bioactive compounds in Bolivia through a multidisciplinary approach Part VI. Evaluation of the antimalarial activity of plants used by Isoceño-Guaran Indians. J Ethnopharmacol. 2004;93:269-77.

13. Muñoz V, Sauvain M, Bourdy G, Callapa J, Bergeron S, Rojas I, Bravo JA, Balderrama L, Ortiz B, Gimenez A. A search for natural bioactive compounds in Bolivia through a multidisciplinary approach. Part I. Evaluation of the antimalarial activity of plants used by the Chacobo Indians. J Ethnopharmacol. 2000;69:127-37.
14. Muñoz V, Sauvain M, Bourdy G, Callapa J, Rojas I, Vargas L, et al. The search for natural bioactive compounds through a multidisciplinary approach in Bolivia. Part II. Antimalarial activity of some plants used by Mosetene indians. J Ethnopharmacol. 2000;69:139-55.

15. Muñoz V, Sauvain M, Bourdy G, Callapa J, Rojas I, Vargas L, et al. A search for natural bioactive compounds in Bolivia through a multidisciplinary approach. Part III. Evaluation of the antimalarial activity of plants used by Alteños Indians. J Ethnopharmacol. 2000;71:123-31.

16. Morais SKR, Silva SG, Portela CN, Nunomura SM, Quignard ELJ, Pohlit AM. Bioactive dihydroxyfuranonaphthoquinones from the bark of Tabebuia incana A.H. Gentry (Bignoniaceae) and HPLC analysis of pau d'arco bark infusions. Acta Amazon. 2007;371:99-102.

17. Andrade-Neto VF, Pohlit AM, Pinto ACS, Silva ECC, Nogueira KL, Melo MRS, et al. In vitro inhibition of Plasmodium falciparum by substances isolated from Amazonian antimalarial plants. Mem Inst Oswaldo Cruz. 2007;102:359-65.

18. Andrade-Neto VF, Brandão MGL, Nogueira F, Rosário VE, Krettli AU. Ampelozyziphus amazonicus Ducke (Rhamnaceae), a medicinal plant used to prevent malaria in the Amazon Region, hampers the development of Plasmodium berghei sporozoites. Int J Parasitol. 2008;38:1505-11.

19. Dolabela MF, Oliveira SG, Nascimento JM, Peres JM, Wagner H, Póvoa $M M$, et al. In vitro antiplasmodial activity of extract and constituents from Esenbeckia febrifuga, a plant traditionally used to treat malaria in the Brazilian Amazon. Phytomedicine. 2008;15:367-72.

20. Henrique MC, Nunomura SM, Pohlit AM. Alcaloides indólicos de cascas de Aspidosperma vargasii e A. desmanthum. Quím Nova. 2010;33:284-7.

21. Rocha e Silva LFR, Pinto ACS, Pohlit AM, Quignard ELJ, Vieira PPR, Tadei WP, et al. In vivo and in vitro antimalarial activity of 4-nerolidylcatechol. Phytother Res. 2011;25:1181-8.

22. Mota ML, Lobo LT, Costa JM, Costa LS, Rocha HA, Rocha e Silva LF, et al. In vitro and in vivo antimalarial activity of essential oils and chemical components from three medicinal plants found in northeastern Brazil. Planta Med. 2012;78:658-64.

23. Rocha e Silva LF, Montoia A, Amorim RCN, Melo MRS, Henrique MC, Nunomura SM, et al. Comparative in vitro and in vivo antimalarial activity of the indole alkaloids ellipticine, olivacine, cryptolepine and a synthetic cryptolepine analog. Phytomedicine. 2012;20:71-6.

24. Pohlit AM, Rocha e Silva LF, Henrique MC, Montoia A, Amorim RCN, Nunomura SM, et al. Antimalarial activity of ellipticine. Phytomedicine. 2012;19:1049.

25. Pohlit AM, Santos EVM, Silva TCM, Morais SKR, Nunomura SM, Struwe L. A rare secoiridoid monoterpene and a xanthone from Tachia grandiflora Maguire \&Weaver. Biochem Syst Ecol. 2012;44:267-9.

26. Torres ZES, Silveira E, Rocha e Silva LF, Lima ES, Vasconcellos MC, Uchoa DA, et al. Chemical composition of Aspidosperma ulei Markgr. and antiplasmodial activity of selected indole alkaloids. Molecules. 2013;18:6281-97.

27. Rocha e Silva LF, Lima ES, Vasconcellos MC, Aranha EP, Costa DS, Santos EVM, et al. In vitro and in vivo antimalarial activity and cytotoxicity of extracts, fractions and a substance isolated from the Amazonian plant Tachia grandiflora (Gentianaceae). Mem Inst Oswaldo Cruz. 2013;108:501-7.

28. Montoia A, Rocha e Silva LF, Torres ZES, Costa DS, Henrique MC, Lima ES, et al. Antiplasmodial activity of synthetic ellipticine derivatives and an isolated analog. Bioorg Med Chem Lett. 2014;24:2631-4.

29. Pereira TB, Rocha e Silva LF, Amorim RCN, Melo MRS, Souza RCZ, Eberlin $\mathrm{MN}$, et al. In vitro and in vivo anti-malarial activity of limonoids isolated from the residual seed biomass from Carapa guianensis (andiroba) oil production. Malar J. 2014;13:317.

30. Garavito G, Rincon J, Arteaga L, Hata Y, Bourdy G, Gimenez A, et al. Antimalarial activity of some Colombian medicinal plants. J Ethnopharmacol. 2006;107:460-2.

31. Bertani S, Bourdy G, Landau I, Robinson JC, Esterre P, Deharo E. Evaluation of French Guiana traditional antimalarial remedies. J Ethnopharmacol. 2005;98:45-54.

32. Vigneron M, Deparis X, Deharo E, Bourdy G. Antimalarial remedies in French Guiana: a knowledge attitudes and practices study. J Ethnopharmacol. 2005;98:351-60. 
33. Jullian V, Bourdy G, Georges S, Maurel S, Sauvain M. Validation of use of a traditional antimalarial remedy from French Guiana, Zanthoxylum rhoifolium Lam. J Ethnopharmacol. 2006;106:348-52.

34. Marti G, Eparvier V, Litaudon M, Grellier P, Guéritte F. A new xanthone from the bark extract of Rheedia acuminata and antiplasmodial activity of its major compounds. Molecules. 2010;15:7106-14.

35. Kvist LP, Christensen SB, Rasmussen HB, Mejia K, Gonzalez A. Identification and evaluation of Peruvian plants used to treat malaria and leishmaniasis. J Ethnopharmacol. 2006;106:390-402.

36. Roumy V, Garcia-Pizango G, Gutierrez-Choquevilca AL, Ruiz L, Jullian V, Winterton P, et al. Amazonian plants from Peru used by Quechua and Mestizo to treat malaria with evaluation of their activity. J Ethnopharmacol. 2007;112:482-9.

37. Valadeau C, Pabon A, Deharo E, Albán-Castillo J, Estevez Y, Lores FA, et al. Medicinal plants from the Yanesha (Peru): evaluation of the leishmanicidal and antimalarial activity of selected extracts. J Ethnopharmacol. 2009:123:413-22.

38. Ruiz L, Maco M, Cobos M, Gutierrez-Choquevilca AL, Roumy V. Plants used by native Amazonian groups from the Nanay River (Peru) for the treatment of malaria. J Ethnopharmacol. 2011;133:917-21.

39. Brandão MGL, Botelho MGA, Krettli AU. Quimioterapia experimental antimalárica com produtos naturais: uma abordagem mais racional? Cien Cult. 1985;37:1152-63.

40. Carvalho LH, Krettli AU. Antimalarial chemotherapy with natural products and chemically defined molecules. Mem Inst Oswaldo Cruz. 1991;86(suppl. II):181-4.

41. Carvalho LH, Brandão MGL, Santos-Filho D, Lopes JLC, Krettli AU. Antimalarial activity of crude extracts from Brazilian plants studied in vivo in Plasmodium berghei-infected mice and in vitro against Plasmodium falciparum in culture. Braz J Med Biol Res. 1991;24:1113-23.

42. Trager W, Jensen JB. Human malaria parasites in continuous culture. Science. 1976;193:673-5.

43. Rieckmann KH, Sax LJ, Campbell GH, Mrema JE. Drug sensitivity of Plasmodium falciparum —an in vitro microtechnique. Lancet. 1978;1:22-3.

44. Lambros C, Vanderberg JP. Synchronization of Plasmodium falciparum erythrocytic stages in culture. J Parasitol. 1979;65:418-20.

45. Rocha e Silva LFR, Magalhães PM, Costa MRF, Alecrim MGC, Chaves FCM, Hidalgo AF, et al. In vitro susceptibility of Plasmodium falciparum Welch field isolates to infusions prepared from Artemisia annua L. cultivated in the Brazilian Amazon. Mem Inst Oswaldo Cruz. 2012;107:859-66.

46. Krettli AU, Adebayo JO, Krettli LG. Testing of natural products and synthetic molecules aiming at new antimalarials. Curr Drug Targets. 2009;10:261-70.

47. Noedl H, Wernsdorfer WH, Miller RS, Wongsrichanalai C. Histidine-rich protein II: a novel approach to malaria drug sensitivity testing. Antimicrob Agents Chemother. 2002;46:1658-64.

48. Nogueira F, Rosario VE. Métodos para avaliação da atividade antimalárica nas diferentes fases do ciclo de vida do Plasmodium. Rev PanAmaz Saude. 2010;1:109-24.

49. Coutinho JP, Aguiar AC, Santos PA, Lima JC, Rocha MG, Zani CL, et al. Aspidosperma (Apocynaceae) plant cytotoxicity and activity towards malaria parasites. Part I: Aspidosperma nitidum (Benth.) used as a remedy to treat fever and malaria in the Amazon. Mem Inst Oswaldo Cruz. 2013:108:974-82.

50. Uchôa VT, Paula RC, Krettli LG, Santana AEG, Krettli AU. Antimalarial activity of compounds and mixed fractions of Cecropia pachystachya. Drug Dev Res. 2010;71:82-91.

51. Mohd ARMR, Afzan A, Ali R, Amir JNF, Wasiman MI, Shiekh ZSH, et al. Effect of selected local medicinal plants on the asexual blood stage of chloroquine resistant Plasmodium falciparum. BMC Complement Altern Med. 2014;14:492

52. Koukouikila-Koussounda F, Abena A, Nzoungani A, Mombouli J, Ouamba J, Kun J, et al. In vitro evaluation of antiplasmodial activity of extracts of Acanthospermum hispidum DC (Asteraceae) and Ficus thonningii blume (Moraceae), two plants used in traditional medicine in the Republic of Congo. Afr J Tradit Complement Altern Med. 2013;10:270-6.

53. Ahmed SA, Gogal RM Jr, Walsh JE. A new rapid and simple non-radioactive assay to monitor and determine the proliferation of lymphocytes: an alternative to $\left[{ }^{3} \mathrm{H}\right]$ thymidine incorporation assay. J Immunol Methods. 1994;170:211-24.

54. Nakayama GR, Caton MC, Nova MP, Parandoosh Z. Assessment of the Alamar blue assay for cellular growth and viability in vitro. J Immunol Methods. 1997;204:205-8.

55. Peters W. Drug resistance in Plasmodium berghei Vincke and Lips, 1948. I. Chloroquine resistance. Exp Parasitol. 1965;17:80-9.

56. Benoit-Vical F, Valentin A, Pelissier Y, Diafouka F, Marion C, Kone-Bamba $D$, et al. In vitro antimalarial activity of vegetal extracts used in West African traditional medicine. Am J Trop Med Hyg. 1996;54:67-71.

57. O'Neill MJ, Bray DH, Boardman P, Phillipson JD, Warhust DC. Plants as sources of antimalarial drugs. Part 1: in vitro test method for the evaluation of crude extracts from plants. Planta Med. 1985;61:394-7.

58. Milliken BW. Traditional anti-malarial medicine in Roraima, Brazil. Econ Bot. 1997;51:212-37.

59. Randrianarivelojosia M, Rasidimanana VT, Rabarison H, Cheplogoi PK, Ratsimbason M, Mulholland DA, et al. Plants traditionally prescribed to treat tazo (malaria) in the eastern region of Madagascar. Malar J. 2003;2:25.

60. Harborne JB, Williams CA. Flavonoid patterns in leaves of the Gramineae. Biochem Syst Ecol. 1976;4:267-80.

61. Senthilraja P, Sunil KS, Kathiresan K. Potential of mangrove derived compounds against dihydrofolate reductase: an in silico docking study. J Comput Biol Bioinform Res. 2012;4:23-7.

62. Milliken W. Plants for malaria. In: Dickeson S, editor. Plants for fever. Medicinal species in Latin America-a bibliographic survey. Kew: The Royal Botanic Garden; 1997.

63. Hidalgo AF. Plantas de uso popular para o tratamento da malária e males associados da área de influência do Rio Solimões e Região de Manaus-AM. Ph.D. Thesis, State University of São Paulo (UNESP), Agronomy Department, Botucatu; 2003.

64. Attioua B, Bernard W, Philippe C. Antiplasmodial activity of constituents isolated from Croton lobatus. Pharm Biol. 2007:45:263-6.

65. Costa MP, Magalhães NSS, Gomes FES, Maciel AM. Uma revisão das atividades biológicas da trans-desidrocrotonina, um produto natural obtido de Croton cajucara. Rev Bras Farmacogn. 2007;17:275-86.

66. Adelekan AM, Prozesky EA, Hussein AA. Bioactive diterpenes and other constituents of Croton steenkampianus. J Nat Prod. 2008;71:1919-22.

67. El-Hadi MA, Bakri YMN, Yousif GM, Hassan SK. Antiplasmodial activity of some medicinal plants used in Sudanese folk-medicine. Environ Health Insights. 2010;4:1-6.

68. Odonne G, Valadeau C, Alban-Castillo J, Stien D, Sauvain M, Bourdy G. Medical ethnobotany of the Chayahuita of the Paranapura basin (Peruvian Amazon). J Ethnopharmacol. 2013:146:127-53.

69. Muthaura CN, Rukunga GM, Chhabra SC, Mungai GM, Njagi EN. Traditional antimalarial phytotherapy remedies used by the Kwale community of the Kenyan Coast. J Ethnopharmacol. 2007;114:377-86.

70. Okokon JE, Nwafor PA. Antiplasmodial activity of root extract and fractions of Croton zambesicus. J Ethnopharmacol. 2009;121:74-8.

71. Mesia GK, Tona GL, Penge O, Lusakibanza M, Nanga TM, Cimanga RK, et al. Antimalarial activities and toxicities of three plants used as traditional remedies for malaria in the Democratic Republic of Congo: Croton mubango, Nauclea pobeguinii and Pyrenacantha staudtii. Ann Trop Med Parasitol. 2005;99:345-57.

72. Mohammed T, Erko B, Giday M. Evaluation of antimalarial activity of leaves of Acokanthera schimperi and Croton macrostachyus against Plasmodium berghei in Swiss albino mice. BMC Complement Altern Med. 2014;14:314.

73. Bantie L, Assefa S, Teklehaimanot T, Engidawork E. In vivo antimalarial activity of the crude leaf extract and solvent fractions of Croton macrostachyus Hocsht. (Euphorbiaceae) against Plasmodium berghei in mice. BMC Complemen Altern Med. 2014;14:79.

74. Thongtan J, Kittakoop P, Ruangrungsi N, Saenboonrueng J, Thebtaranonth Y. New antimycobacterial and antimalarial 8,9-secokaurane diterpenes from Croton kongensis. J Nat Prod. 2003;66:868-70.

75. Li XC, Jacob MR, Pasco DS, Elsohly HN, Ninrod AC, Walker LA, et al. Phenolic compounds from Miconia myriantha inhibiting Candida aspartic proteases. J Nat Prod. 2001;64:1282-5.

76. Serpeloni MJ, Barcelos MGR, Mori PM, Yanagui K, Vilegas W, Varanda AE, et al. Cytotoxic and mutagenic evaluation of extracts from plant species 
of the Miconia genus and their influence on doxorubicin-induced mutagenicity: an in vitro analysis. Exp Toxicol Pathol. 2011;63:499-504.

77. Cunha WR, Crevelin EJ, Arantes GM, Crotti AEM, Silva MLAE, Furtado NAJC, et al. A study of the trypanocidal activity of triterpene acids isolated from Miconia species. Phytother Res. 2006;20:474-8.

78. Suffredini IB, Paciencia MLB, Varella AD, Younes RN. In vitro cytotoxic activity of Brazilian plant extracts against human lung, colon and CNS solid cancers and leukemia. Fitoterapia. 2007;78:223-6.

79. Mesquita ML, Paula JE, Pessoa C, Moraes MO, Costa-Lotufo LV, Grougnet $\mathrm{R}$, et al. Cytotoxic activity of Brazilian cerrado plants used in traditional medicine against cancer cell lines. J Ethnopharmacol. 2009;123:439-45.

80. Boyom FF, Ngouana V, Zollo PHA, Menut C, Bessiere JM, Gut J, et al. Composition and anti-plasmodial activities of essential oils from some Cameroonian medicinal plants. Phytochemistry. 2003;64:1269-75.

81. Fischer DCH, Gualda NCA, Bachiega D, Carvalho CS, Lupo FN, Bonotto SV, et al. In vitro screening for antiplasmodial activity of isoquinoline alkaloids from Brazilian plant species. Acta Trop. 2004;92:261-6.

82. Odugbemi TO, Akinsulire OR, Aibinu IE, Fabeku PO. Medicinal plants useful for malaria therapy in Okeigbo, Ondo State, southwest Nigeria. Afr J Trad CAM. 2007:4:191-8.

83. Botsaris AS. Plants used traditionally to treat malaria in Brazil: the archives of Flora Medicinal. J Ethnobiol Ethnomed. 2007;1:13-8.

84. Koudouvo K, Karou DS, Kokou K, Essien K, Aklikokou K, Glitho IA, et al. An ethnobotanical study of antimalarial plants in Togo maritime region. J Ethnopharmacol. 2011;134:183-90.

85. Tsabang N, Fokou PVT, Tchokouaha LRY, Noguem B, Bakarnga-Via I, Nguepi MSD, et al. Ethnopharmacological survey of Annonaceae medicinal plants used to treat malaria in four areas of Cameroon. J Ethnopharmacol. 2012;139:171-80.

86. de Mesquita ML, Grellier P, Mambu L, Paula JE, Espindola LS. In vitro antiplasmodial activity of Brazilian cerrado plants used as traditional remedies. J Ethnopharmacol. 2007;110:165-70.

87. Moreira IC, Roque NF, Vilegas W, Zalewski CA, Lago JHG, Funasaki M. Genus Xylopia (Annonaceae): chemical and biological aspects. Chem Biodivers. 2013;10:1921-43.

88. Martins D, Alvarenga MA, Roque NF, Felício JD. Diterpenes and alkaloids from Brazilian Xylopia species. Quím Nova. 1995;18:14-6.

89. Böhlke M, Guinaudeau H, Angerhofer CK, Wongpanich V, Soejarto DD, Farnsworth NR. Costaricine, a new antiplasmodial bisbenzylisoquinoline alkaloid from Nectandra salicifolia trunk bark. J Nat Prod. 1996:59:576-80

90. Chokchaisiri R, Chaichompoo W, Chalermglin R, Suksamrarn A. Potent antiplasmodial alkaloids and flavonoids from Dasymaschalon acuminatum. Rec Nat Prod. 2015;9:243-6.

91. Mbah JA, Tane P, Ngadjui BT, Connolly JD, Okunji CC, Iwu MM, et al. Antiplasmodial agents from the leaves of Glossocalyx brevipes. Planta Med. 2004;70:437-40.

92. Graziose R, Rathinasabapathy T, Lategan C, Poulev A, Smith PJ, Grace $M$, et al. Antiplasmodial activity of aporphine alkaloids and sesquiterpene lactones from Liriodendron tulipifera L. J Ethnopharmacol. 2011;133:26-30.

93. Langat MK, Crouch NR, Pohjala L, Tammela P, Smith PJ, Mulholland DA. Ent-kauren-19-oic acid derivatives from the stem bark of Croton pseudopulchellus. Pax Phytochemistry Lett. 2012;5:414-8.

94. Melo GF, Machado IC, Luceno M. Reprodución de tres especies de Clidemia (Melastomataceae) en Brasil. Rev Biol Trop. 1999;47:359-63.

95. Abdellaoui SE, Destandau E, Krolikiewicz-Renimel I, Cancellieri P, Toribio A, Jeronimo-Monteiro V, et al. Centrifugal partition chromatography for antibacterial bio-guided fractionation of Clidemia hirta roots. Sep Purif Technol. 2014;123:221-8.

96. Deharo E, Bourdy G, Quenevo C, Muñoz V, Ruiz G, Sauvain M. A search for natural bioactive compounds in Bolivia through a multidisciplinary approach. Part V. Evaluation of the antimalarial activity of plants used by the Tacana Indians. J Ethnopharmacol. 2001;77:91-8.

97. Mors WB, Rizzini CT, Pereira NA. Medicinal plants of Brazil. In: DeFilipps RA, editor. Algonac: Reference Publication; 2000, pp 501.

98. Souza MP, Matos MEO, Matos FJA, Machado MIL, Craveiro AA. Constituintes químicos ativos e propriedades biológicas de plantas medicinais brasileiras. Fortaleza: Editora UFC; 2004.

99. Rekshmyd'dharan S, Roy A. Epicatechin-nature's extraordinary therapeutic agent: a review. Int J PharmTech Res. 2013;5:1816-22.
100. Ginsburg H, Deharo E. A call for using natural compounds in the development of new antimalarial treatments - an introduction. Malar J. 2011;10(Suppl 1):S1.

101. Gansane A, Sanon S, Ouattara LP, Traore A, Hutter S, Ollivier E, et al. Antiplasmodial activity and toxicity of crude extracts from alternatives parts of plants widely used for the treatment of malaria in Burkina Faso: contribution for their preservation. Parasitol Res. 2010;106:335-40.

102. Gessler MC, Nkunya MH, Mwasumbi LB, Heinrich M, Tanner M. Screening of Tanzanian medicinal plants for antimalarial activity. Acta Trop. 1994;56:65-77.

103. Kirira PG, Rukunga GM, Wanyonyi AW, Muregi FM, Gathirwa JW, Muthaura CN, et al. Antiplasmodial activity and toxicity of extracts of plants used in traditional malaria therapy in Meru and Kilifi Districts of Kenya. J Ethnopharmacol. 2006;106:403-7.

104. Muganga RL, Angenot L, Tits M, Frédérich M. Antiplasmodial and cytotoxic activities of Rwandan medicinal plants used in the treatment of malaria. J Ethnopharmacol. 2010;128:52-7.

105. Nguta JM, Mbaria JM, Gakuya DW, Gathumbi PK, Kiama SG. Traditional antimalarial phytotherapy remedies used by the South Coast community, Kenya. J Ethnopharmacol. 2010;131:256-67.

106. Penali L, Mulholland DA, Tano KD, Cheplogoi PK, Randrianarivelojosia M. Low antiplasmodial activity of alkaloids and amides from the stem bark of Zanthoxylum rubescens (Rutaceae). Parasite. 2007;14:161-4.

107. Rukunga GM, Gathirwa JW, Omar SA, Muregi FW, Muthaura CN, Kirira PG, et al. Anti-plasmodial activity of the extracts of some Kenyan medicinal plants. J Ethnopharmacol. 2009;121:282-5.

108. Tchinda AT, Fuendjiep V, Sajjad A, Matchawe C, Wafo P, Khan S, et al. Bioactive compounds from the fruits of Zanthoxylum leprieurii. Pharmacol Online. 2009;1:406-15.

109. Traore MS, Baldé MA, Diallo MST, Baldé Diané ESS, Camara A, Diallo A, et al. Ethnobotanical survey on medicinal plants used by Guinean traditional healers in the treatment of malaria. J Ethnopharmacol. 2013;150:1145-53.

110. Weenen H, Nkunya MHH, Bray DH, Mwasumbi LB, Kinabo LS, Kilimali VAEB, et al. Antimalarial activity of Tanzanian plants. Part 2. Antimalarial compounds containing an a, $\beta$-unsaturated carbonyl moiety from Tanzanian medicinal plants. Planta Med. 1990;56:371-3.

111. Kato A, Moriyasu M, Ichimaru M, Nishiyama Y, Juma F, Nganga J, et al Isolation of alkaloidal constituents of Zanthoxylum usambarense and Zanthoxylum chalybeum using ion-pair HPLC. J Nat Prod. 1996;59:316-9.

112. Gakunju DMN, Mberu EK, Dossaji SF, Gray Al, Waigh RD, Waterman PG, et al. Potent antimalarial activity of the alkaloid nitidine, isolated from a Kenyan herbal remedy. Antimicrob Agents Chemother. 1995;39:2606-9.

113. Avwioro GO, lyiola S, Enoghayin El. Effects of some Nigerian antimalarial medicinal plants on glucose levels in Wistar rats. Arch Appl Sci Res. 2010;2:112-6.

114. Hemshekhar M, Santhosh MS, Kemparaju K, Girish KS. Emerging roles of anacardic acid and its derivatives: a pharmacological overview. Basic Clin Pharmacol Toxicol. 2012;110:122-32.

115. Cui L, Miao J, Furuya T, Fan Q, Li X, Rathod PK, et al. Histone acetyltransferase inhibitor anacardic acid causes changes in global gene expression during in vitro Plasmodium falciparum development. Eukaryot Cell. 2008;7:1200-10.

116. Yenesew ABIY, Twinomuhwezi H, Kabaru JM, Akala HM, Kiremire BT, Heydenreich $M$, et al. Antiplasmodial and larvicidal flavonoids from Derris trifoliata. B Chem Soc Ethiopia. 2009;23:409-14.

117. Mesfin A, Giday M, Animut A, Teklehaymanot T. Ethnobotanical study of antimalarial plants in Shinile District, Somali Region, Ethiopia, and in vivo evaluation of selected ones against Plasmodium berghei. J Ethnopharmacol. 2012;139:221-7.

118. Sangian H, Faramarzi H, Yazdinezhad A, Mousavi SJ, Zamani Z, Noubarani $M$, et al. Antiplasmodial activity of ethanolic extracts of some selected medicinal plants from the northwest of Iran. Parasitol Res. 2013;112:3697-701.

119. Falade $\mathrm{MO}$, Akinboye DO, Gbotosho GO, Abiodun OO, Ajaiyeoba EO, Happi TC, et al. In vitro and in vivo antimalarial activity of Ficus thonningii Blume (Moraceae) and Lophira alata Banks (Ochnaceae), identified from the ethnomedicine of the Nigerian Middle Belt. J Parasitol Res. 2014;2014:972853.

120. Upadhyay HC, Sisodia BS, Agrawal J, Pal A, Darokar MP, Srivastava SK. Antimalarial potential of extracts and isolated compounds from four species of genus Ammannia. Med Chem Res. 2014;23:870-6. 
121. Musila MF, Dossaji SF, Nguta JM, Lukhoba CW, Munyao JM. In vivo antimalarial activity, toxicity and phytochemical screening of selected antimalarial plants. J Ethnopharmacol. 2013;146(2):557-61.

122. Nguta JM, Mbaria JM. Brine shrimp toxicity and antimalarial activity of some plants traditionally used in treatment of malaria in Msambweni district of Kenya. J Ethnopharmacol. 2013;148:988-92

123. Gathirwa W, Rukunga GM, Mwitari PG, Mwikwabe NM, Kimani CW Muthaura CN, et al. Traditional herbal antimalarial therapy in Kilifi district, Kenya. J Ethnopharmacol. 2011;134:434-42.

124. Jiménez-Díaz MB, Viera S, Ibáñez J, Mulet T, Magán-Marchal N, Garuti H, et al. A new in vivo screening paradigm to accelerate antimalarial drug discovery. PLoS One. 2013;8:e66967.

125. Blair S, Correa A, Madrigal B, Zuluaga CB, Franco HD. Plantas antimaláricas, una revisión bibliográfica. Medellin: Universidad de Antioquia; 1991. p. 214.

126. Osorio E, Arango GJ, Jimenez N, Alzate F, Ruiz G, Gutierrez D. Antiprotozoal and cytotoxic activities in vitro of Colombian Annonaceae. $J$ Ethnopharmacol. 2007;11:630-5.
127. Steele JCP, Phelps RJ, Simmonds MSJ, Warhurst DC, Meyer DJ. Two novel assays for the detection of hemin-binding properties of antimalarials evaluated with compounds isolated from medicinal plants. J Antimicrob Chemother. 2002;50:25-31.

128. Adia MM, Anywar NG, Byamukama R, Kamatenesi-Mugisha M, Sekagya Y, Kakudidi EK, et al. Medicinal plants used in malaria treatment by Prometra herbalists in Uganda. J Ethnopharmacol. 2014;155:580-8.

129. Mujtaba Shah G, Abbasi AM, Khan N, Guo X, Khan MA, Hussain M, et al. Traditional uses of medicinal plants against malarial disease by the tribal communities of Lesser Himalayas-Pakistan. J Ethnopharmacol. 2014;155:450-62.

\section{Submit your next manuscript to BioMed Central and we will help you at every step:}

- We accept pre-submission inquiries

- Our selector tool helps you to find the most relevant journal

- We provide round the clock customer support

- Convenient online submission

- Thorough peer review

- Inclusion in PubMed and all major indexing services

- Maximum visibility for your research

Submit your manuscript at www.biomedcentral.com/submit
() Biomed Central 